\title{
Antibiotics in the clinical pipeline in 2011
}

\author{
Mark S Butler and Matthew A Cooper \\ The emergence of multi-drug-resistant bacteria and the lack of new antibiotics in the antibiotic drug development pipeline, \\ especially those with new modes of action, is a major health concern. This review lists the $\mathbf{2 0}$ new antibiotics launched \\ since $\mathbf{2 0 0 0}$ and records the $\mathbf{4 0}$ compounds currently in active clinical development. Compounds in the pipeline from new \\ antibiotic classes are reviewed in detail with reference to their development status, mode of action, spectrum of activity \\ and lead discovery. In addition, the NP or synthetic derivation is discussed, with activity against Gram-negative bacteria \\ highlighted.
}

The Journal of Antibiotics (2011) 64, 413-425; doi:10.1038/ja.2011.44; published online 18 May 2011

Keywords: clinical trials; drug development; drug discovery; natural product; resistance

\section{INTRODUCTION}

The discovery of sulfonamides and $\beta$-lactam antibiotics in the 1930s had a profound impact on human health by enabling rapid treatment of patients with bacterial infections that previously had often proved fatal. ${ }^{1,2}$ Over the next 40 years, now seen as the "golden era" of antibiotic research, the majority of antibiotic drug classes in use today were discovered. Since 1970, most newly approved antibiotics (see Table 1 for antibiotics launched since 2000) have been based on these known scaffolds, with the exception of linezolid (1), an oxazolidinone; daptomycin (2), a lipopeptide; and the topical antibiotics mupirocin (launched 1985), a pseudomonic acid, and retapamulin (3), a pleuromutilin derivative. ${ }^{3}$

The lack of new antibiotics, the emergence of multi-drug-resistant bacteria and the economic and regulatory challenges of antibiotic research have been discussed in depth. ${ }^{4-20}$ The potential for a major antibiotic healthcare crisis is best summarized by the Infectious Diseases Society of America (IDSA) $)^{21-23}$ and the European Centre for Disease Prevention and Control, ${ }^{16,24}$ both of which report that there are only a few potential drugs in clinical development that (1) offer significant benefits over existing drugs and (2) that target Gramnegative, hospital-based infections. Gram-negative bacteria are especially difficult to kill as they have an additional outer membrane permeability barrier that compounds need to surmount to be efficacious, as well as often possessing multiple efflux pumps, and antibiotic and target-modifying enzymes. ${ }^{20,25,26}$ Despite these considerable challenges, antibiotic drug development is in fact well validated, with a historically high approval rate following successful completion of phase-I studies. ${ }^{15}$

This article reviews all antibiotics that have been launched since 2000, and compounds that are currently undergoing clinical development in phase-I, II or III trials, and under regulatory evaluation as of early 2011. Compounds representing new antibiotic classes are reviewed in detail with reference to their development status, mode of action, spectra of activity and historical discovery. New combinations of previously approved antibiotics have not been included. In addition, the origin of the drug pharmacophore; the natural product (NP) or synthetic derivation, is also reviewed. These data were obtained by reviewing the journal literature and internet resources such as company webpages, clinical trial registers and biotechnologyrelated newsletters. Some compounds where there has been no evidence of recent development have been excluded from this review. Every endeavor has been undertaken to ensure that these data are accurate, but it is possible that compounds undergoing early clinical development have been overlooked.

The drug development and approval process, as well as commonly used abbreviations associated with antibiotic development used in this review, are summarized as follows:

- Before clinical trials can start, an Investigational New Drug Application (IND) must be approved by the US Food and Drug Administration (FDA), European Medicines Agency (EMA), Japanese Pharmaceuticals and Medical Devices Agency (PMDA) or equivalent agency.

- The clinical indication for clinical trial approval in general falls within one of the following categories of antibacterial infections: Clostridium difficile infections (CDI), C. difficile-associated diarrhea (CDAD), skin and skin structure infections (SSSi), which are further divided into complicated (cSSSi), uncomplicated (uSSSi) and acute bacterial (ABSSSi), community/hospital acquired pneumonia (CAP/ $\mathrm{HAP})$, community-acquired bacterial pneumonia (CABP), urinary tract infections (UTI), complicated intra-abdominal infections (cIAI) and tuberculosis (TB). 
Table 1 New antibacterial drugs launched since 2000 divided into NP- and synthetically-derived listed by antibiotic class

\begin{tabular}{|c|c|c|c|}
\hline Year & Name & Class & Lead (source) \\
\hline \multicolumn{4}{|c|}{ NP-derived } \\
\hline 2002 & Biapenem (4) & $\beta$-Lactam (carbapenem) & Thienamycin (actinomycete) \\
\hline 2005 & Doripenem (6) & $\beta$-Lactam (carbapenem) & Thienamycin (actinomycete) \\
\hline 2009 & Tebipenem pivoxil (7) & $\beta$-Lactam (carbapenem) & Thienamycin (actinomycete) \\
\hline 2008 & Ceftobiprole medocaril (8) & $\beta$-Lactam (cephalosporin) & Cephalosporin (fungus) \\
\hline 2003 & Daptomycin $(2)^{a}$ & Lipopeptide & Daptomycin (actinomycete) \\
\hline 2005 & $\overline{\text { Tigecycline (11) }}$ & Tetracycline & Tetracycline (actinomycete) \\
\hline 2007 & Retapamulin (3) & Pleuromutilin & Pleuromutilin (fungus) \\
\hline 2009 & $\overline{\text { Telavancin (12) }}$ & Glycopeptide & Vancomycin (actinomycete) \\
\hline \multicolumn{4}{|c|}{ Synthetically-derived } \\
\hline 2004 & Gemifloxacin (16) & Fluoroquinolone & Quinolone \\
\hline 2007 & Garenoxacin (17) & Quinolone & Quinolone \\
\hline 2008 & Sitafloxacin (18) & Fluoroquinolone & Quinolone \\
\hline 2009 & Antofloxacin $(19)^{c}$ & Fluoroquinolone & Quinolone \\
\hline 2009 & Besifloxacin (20) & Fluoroquinolone & Quinolone \\
\hline
\end{tabular}

Abbreviation: NP, natural product.

aFirst member of a new antibiotic class approved for human use underlined. Please note that pleuromutilin derivatives had been previously used in animal health. ${ }^{132}$

${ }^{\text {b} F o r ~ t o p i c a l ~ u s e ~ o n l y . ~}$

cJointly developed by the Shanghai Institute of Materia Medica and Anhui Global Pharmaceutical and approved for use in China in 2009. ${ }^{133-135}$

- Upon successful completion of phase-III clinical trials, a New Drug Application (NDA/FDA and PMDA) or a Marketing Authorization Application (MAA/EMA) must be submitted to seek approval to be able to market the drug.

\section{ANTIBACTERIAL DRUGS LAUNCHED SINCE 2000}

Since 2000, 20 new antibiotics have been launched worldwide (Table 1; Figures 1 and 2), of which 11 are NP-derived and nine are synthetically derived. A majority of the NP-derived antibiotics belong to the $\beta$-lactam class, with the other five belonging to separate classes. Noteworthy among the NP-derived antibiotics are daptomycin (2) and retapamulin (3), the first members of the lipopeptide and pleuromutilin classes, respectively, approved for use in humans. Within the synthetically derived antibiotics there is minimal diversity, with eight of the nine antibiotics belonging to the quinolone class and linezolid (1), which is the first and, to date, the only representative of the oxazolidinone class.

\section{COMPOUNDS UNDERGOING CLINICAL EVALUATION}

This section describes compounds and their structures currently undergoing clinical trials and under regulatory evaluation for the treatment of bacterial infections as of early 2011 (phase-III/(NDA) in Table 2, with structures in Figure 3; phase-II in Table 3, with structures in Figures 3 and 4; and phase-I in Table 4, with structures in Figure 7). Compounds that represent new antibiotic classes are underlined in the tables and a summary of their development status, mode of action and discovery is discussed in detail.

Phase-III trials and NDA/MAA applications

Fidaxomicin (21), which is being developed by Optimer Pharmaceuticals (San Diego, CA, USA), is currently undergoing evaluation for market approval by the FDA (NDA finalized in November 2010) and EMA (MAA submitted in September 2010) for the treatment of patients with CDIs. ${ }^{27,28} \mathrm{C}$. difficile is a spore-forming Gram-positive anaerobe that can cause serious intestinal infections through secreted toxins that cause inflammation of the colon, severe diarrhea, fever with an elevated white blood cell count, and intestinal paralysis and sepsis in widespread infections..$^{29,30}$ CDI can be lethal, especially in compromised patients, and there are increasing worldwide outbreaks of new virulent and highly toxic strains of C. difficile. ${ }^{31}$ Currently only metronidazole and vancomycin are routinely used to treat CDI, and development of new agents is urgently required. ${ }^{32}$ Data from two phase-III trials indicated that fidaxomicin (21) was able to achieve the primary endpoint of clinical cure, which was defined as patients not requiring any further CDI therapy 2 days after the completion of the fidaxomicin (21) course. ${ }^{33,34}$ In addition, fidaxomicin (21) showed a higher global cure rate than vancomycin and a lower recurrence rate, which was defined as no recurrence within 4 weeks. Fidaxomicin (21) belongs to a family of actinomycete-derived macrolactone with a complex history. The structure of $\mathbf{2 1}$, which was named tiacumicin-B, and a series of analogs were reported by Abbott Laboratories in a patent filed in $1986^{35}$ and published in 1987. ${ }^{36,37}$ Fidaxomicin (21) and analogs have identical structures to the lipiarmycins whose isolation and biological activity, and structure elucidation, were reported in $1975^{38-41}$ and $1987^{42,43}$ respectively, and the clostomicins whose activity and structures were reported in $1986 .{ }^{44}$ Early on these macrolactones were shown to be inhibitors of the bacterial DNAdependent RNA polymerase. ${ }^{41,45-47}$ Recent studies have shown that these macrolactones impede the de novo initiation of RNA synthesis through binding to the ó70-subunit region-3.2 and the RNA polymerase $\beta^{\prime}$-subunit switch-2 element, which controls the clamping of the promoter DNA in the RNA polymerase active-site cleft. ${ }^{48}$ In 


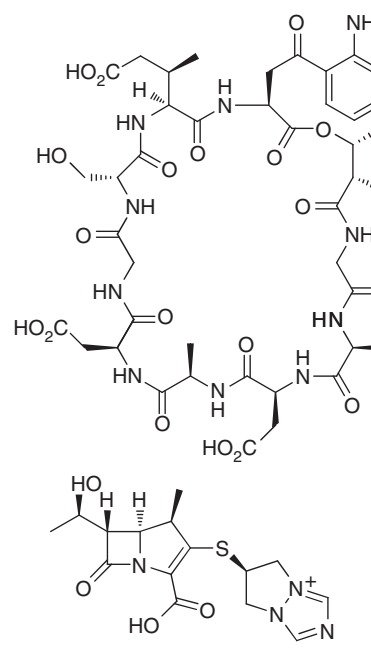<smiles>CCCCC(=O)NC(Cc1c[nH]c2ccccc12)C(=O)NC(CC(N)=O)C(=O)NC(CCC(=O)O)C(=O)N[C@@H](Cc1ccc(N)cc1)NC(=O)CCCCCN</smiles>

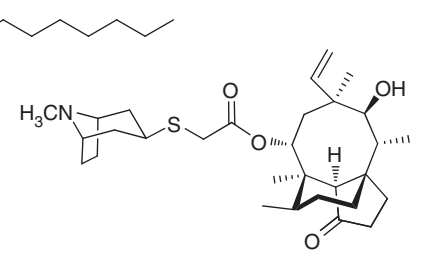

retapamulin (3)<smiles>CCCCCCCCCCCCC(C)O</smiles><smiles>CC(O)C1C(=O)N2CC1C(C)C(SC1CNC(CNS(N)(=O)=O)C1)=C2C(=O)O</smiles><smiles>CC(O)C1C(=O)N2C(C(=O)OCOC(=O)C(C)(C)C)=C(SC3CN(C4=NCCS4)C3)C(C)C12</smiles><smiles>Cc1oc(=O)oc1COC(=O)N1CCC(N2CC/C(=C\C3=C(C(=O)O)N4C(=O)[C@@H](NC(=O)/C(=N\O)c5nsc(N)n5)[C@H]4SC3)C2=O)C1</smiles><smiles>CCO/N=C(/C(=O)NC1C(=O)N2C(C(=O)O)=C(Sc3nc(-c4cc[n+](C)cc4)cs3)CS[C@H]12)c1nsc(NP(=O)(O)O)n1</smiles>

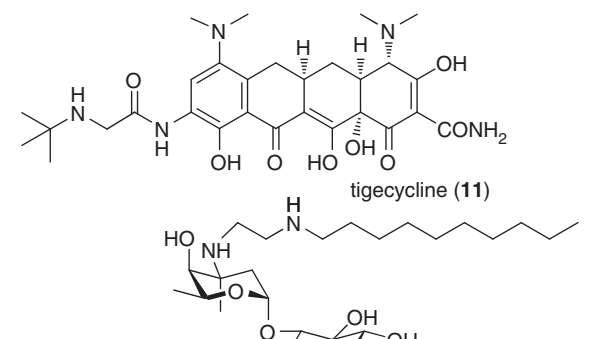

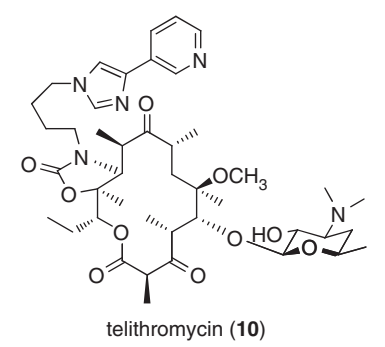

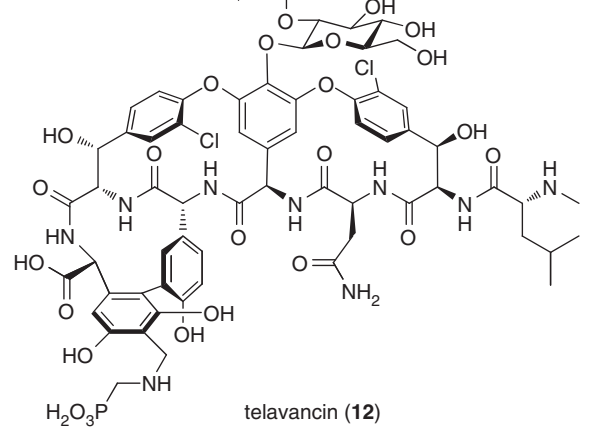

Figure 1 Structures of NP-derived antibiotics launched since 2000.

addition to showing activity against Gram-positive bacteria, these macrolactones also function against multi-drug-resistant tuberculosis (TB) strains through the same mechanism. ${ }^{49}$

\section{Phase-II trials}

In December 2009, Nanotherapeutics (Alachua, FL, USA) acquired ramoplanin (30) from Oscient Pharmaceuticals, a company undergoing bankruptcy proceedings that had in turn licensed the North American rights from Vicuron (Figure 5). ${ }^{50}$ Ramoplanin (30), which is the abbreviation commonly used for ramoplanin- $A_{2}$, has been evaluated in phase-II trials for the treatment of $C$. difficile-associated diarrhea, with plans to undertake phase-III trials. ${ }^{50}$ The ramoplanin lipopeptide antibiotic complex produced by Actinoplanes sp. was first described by Gruppo Lepetit S.p.A. in 1984, ${ }^{51,52}$ with structures reported in 1989. ${ }^{53-55}$ Ramoplanin (30) has been shown to bind to the peptidoglycan intermediate Lipid-II, which disrupts bacterial cell wall synthesis, causing bacterial cell death. ${ }^{56-58}$ An X-ray structure of ramoplanin (30) in the presence of detergents showed that $\mathbf{3 0}$ forms an intimate and highly amphipathic dimer, which allowed a model of 30 binding to Lipid-II to be proposed. ${ }^{59}$

GSK1322322 (34), ${ }^{60-63}$ which is being developed by GlaxoSmithKline (GSK, Brentford, UK), has recently completed a phase-II trial for acute bacterial skin and skin structure infections (ABSSSis). ${ }^{64}$ As well as possessing potent activity against methicillin-resistant Staphylococcus aureus (MRSA), this compound also shows activity against the respiratory pathogens Haemophilus influenzae and Streptococcus pneumoniae. GSK1322322 (34) targets bacterial peptide deformylase, a metallo-hydrolase enzyme that catalyzes the removal of the formyl group from the $\mathrm{N}$-terminal methionine following translation. ${ }^{65,66}$ BB83698 (47) (Oscient) ${ }^{66,67}$ and LBM-415 (48) (Novartis, Basel, Switzerland $)^{66,68,69}$ were the first peptide deformylase inhibitors to reach phase-I trials, but no further development of either compound 
<smiles>CC(=O)NCC1CN(c2ccc(N3CCOCC3)c(F)c2)C(=O)O1</smiles>

linezolid (1)<smiles>CNC1CCCN(c2c(F)cc3c(=O)c(C(=O)O)cn(C4CC4)c3c2OC)C1</smiles>

balofloxacin (15)<smiles>NC1CN(c2c(F)cc3c(=O)c(C(=O)O)cn(C4CC4F)c3c2Cl)CC12CC2</smiles>

sitafloxacin (18)<smiles>CC1OCc2c(C3(N)CC3)c(F)cc3c(=O)c(C(=O)O)cn1c23</smiles>

prulifloxacin (13)

pazufloxacin (14)<smiles>CO/N=C1\CN(c2nc3c(cc2F)c(=O)c(C(=O)O)cn3C2CC2)CC1CN</smiles>

gemifloxacin (16)<smiles>CC1COc2c(N3CCN(C)CC3)c(F)c(N)c3c(=O)c(C(=O)O)cn1c23</smiles>

antofloxacin (19)<smiles>CC1NCc2cc(-c3ccc4c(=O)c(C(=O)O)cn(C5CC5)c4c3OC(F)F)ccc21</smiles>

garenoxacin (17)<smiles>N[C@H]1CCCCN(c2c(F)cc3c(=O)c(C(=O)O)cn(C4CC4)c3c2Cl)C1</smiles>

Figure 2 Structures of synthetically derived antibiotics launched since 2000.

Table 2 Compounds in phase-III clinical trials or under NDA/MAA evaluation

\begin{tabular}{|c|c|c|c|}
\hline Name (synonym) & Lead compound (source) & Mode of action & Development status, indication (Developer) \\
\hline $\begin{array}{l}\text { Fidaxomicin (21) (tiacumicin-B, } \\
\text { difimicin, OPT-80) } \\
27-31,33,34,36,37,48\end{array}$ & Tiacumicin-B (21) (NP) & RNA synthesis inhibition & $\begin{array}{l}\text { CDI MAA in September } 2010 \text { and NDA } \\
\text { November } 2010 \text { (Optimer) }\end{array}$ \\
\hline $\begin{array}{l}\text { Amadacycline (22) (PTK-0796; } \\
\text { MK-2764) }\end{array}$ & Tetracycline (NP) & Protein synthesis inhibition & Phase-III cSSSi (Paratek/Novartis) \\
\hline $\begin{array}{l}\text { Torezolid phosphate (23) } \\
(\text { TR-701, DA-7218) })^{138-140}\end{array}$ & Oxazolidinone (S) & Protein synthesis inhibition & Phase-III ABSSSI (Trius Therapeutics) \\
\hline Oritavancin (24) $141-145$ & $\begin{array}{l}\text { Glycopeptide } \\
\text { (chloroeremomycin) (NP) }\end{array}$ & Cell wall production inhibition & Phase-III ABSSSi (The Medicines Company) \\
\hline Dalbavancin $(25)^{145-149}$ & Glycopeptide (A40926) (NP) & Cell wall production inhibition & Phase-III ABSSSi (Durata Therapeutics) \\
\hline Cethromycin (26) (ABT-773) $)^{150-154}$ & Erythromycin (NP) & Protein synthesis inhibition & $\begin{array}{l}\text { CAP NDA submitted October } 2008 \text { but } \\
\text { rejected due to "no efficacy" } 2 \text { June } 2009 \\
\text { (Advanced Life Sciences) }\end{array}$ \\
\hline
\end{tabular}

Abbreviation: NDA/MAA, New Drug Application/Marketing Authorization Application.

was undertaken. ${ }^{66}$ The original lead compound, actinonin $(49),{ }^{70,71}$ was identified by Vicuron as a peptide deformylase inhibitor by searching for NPs that possessed a hydroxamate metal chelating group and methionine-like structures (Figure 6). ${ }^{72}$

NVC-422 (35) ( $N, N$-dichloro-2,2-dimethyltaurine), which was discovered by NovaBay Pharmaceuticals (Emeryville, CA, USA), is being evaluated in a phase-II trial to prevent urinary catheter blockade and encrustation. ${ }^{73}$ NovaBay has also been working with Alcon (Hünenberg, Switzerland) for eye, ear and sinus infections, and contact lens care, and with Galderma (Les Templiers, France) for acne, impetigo and other dermatological indications. ${ }^{74}$ NVC-422 (35) was designed to be a more stable derivative of the naturally occurring oxidant $\mathrm{N}$-dichlorotaurine. ${ }^{75-77} \mathrm{~N}$-chloro derivatives of amino acids and peptides can act as oxidants, and are involved in the human immune defense system in the killing of pathogens and control of inflammatory responses. ${ }^{78} \mathrm{~N}$-dichlorotaurine was first identified in 1971, when chlorination of amino acids by the myeloperoxidase system $^{79,80}$ was identified as having an important role in the human body because of its relatively high concentration and superior stability over other chlorinated amino acids. ${ }^{78}$

PMX-30063 (structure not released), which was discovered by researchers at the University of Pennsylvania and PolyMedix (Radnor, PA, USA), is currently being evaluated in phase-II trials as a treatment of Staphylococcus infections, including MRSA. ${ }^{81,82}$ PMX-30063 is a membrane-active antimicrobial arylamide oligomer mimetic of a host defense protein, ${ }^{83-86}$ which is bactericidal against both Gram-positive and Gram-negative bacteria, and has a has a very low propensity for resistance development. ${ }^{82}$

Bedaquiline (36) (TMC207, R207910, JNJ-16175328) is being developed by Tibotec (Beerse, Belgium) and the Global Alliance for TB Drug Development (New York, NY, USA) ${ }^{87}$ for the treatment of patients with pulmonary $\mathrm{TB}^{88}$ Bedaquiline (36) has successfully completed one phase-II trial and was found to be efficacious against multi-drug-resistant TB. ${ }^{89,90}$ Whole-cell screening of Mycobacterium smegmatis, a surrogate for screening against $M$. tuberculosis, identified a series of diarylquinolines and structure optimization led to the 


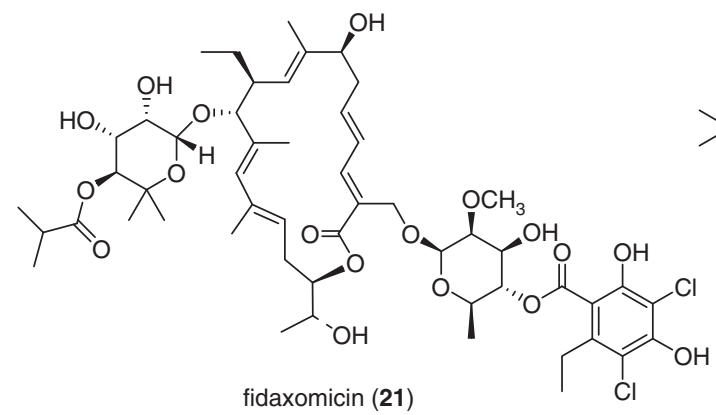

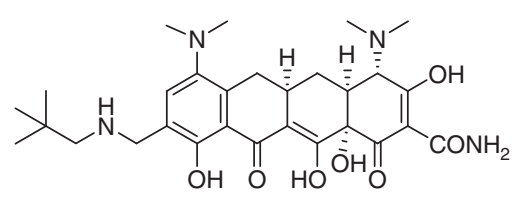

amadacycline (22)<smiles>Cn1nnc(-c2ccc(-c3ccc(N4CC(COP(=O)(O)O)OC4=O)cc3F)cn2)n1</smiles>

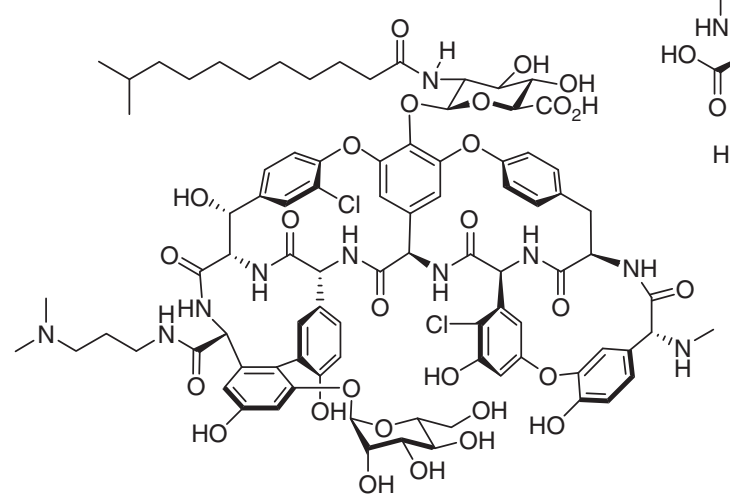

dalbavancin (25)

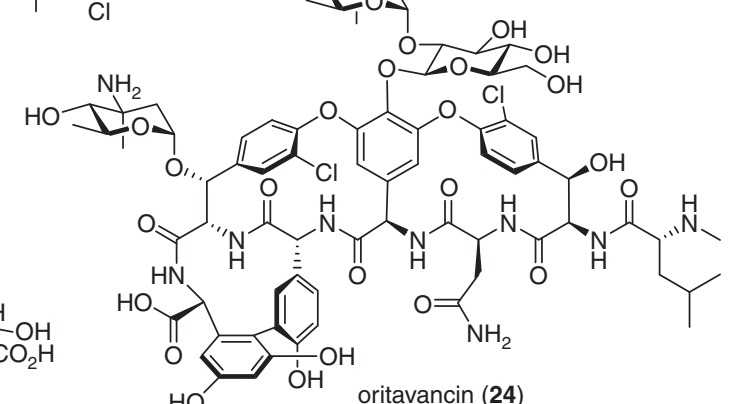

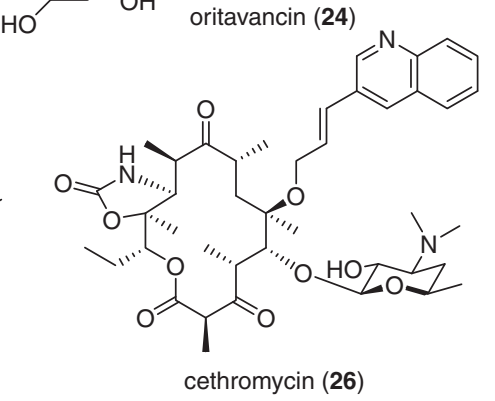

Figure 3 Structures of compounds in phase-III clinical trials or under NDA/MAA evaluation. NDA/MAA, New Drug Application/Marketing Authorization Application.

Table 3 Compounds in, or that have recently completed, phase-II clinical trials

\begin{tabular}{|c|c|c|c|}
\hline Name (synonym) & Lead compound (source) & Mode of action & Development status, indication (Developer) \\
\hline ACHN-490 (27) $155-157$ & Aminoglycoside (NP) & Protein synthesis inhibition & UTI and pyelonephritis (Achaogen) \\
\hline BC-3781 (28) $132,158-160$ & Pleuromutilin (NP) & Protein synthesis inhibition & ABSSSi (Nabriva) \\
\hline CB-183,315 (29) 161,162 & Daptomycin (NP) & Membrane depolarization & CDAD (Cubist) \\
\hline Ramoplanin (30) $)^{50-59}$ & Ramoplanin (NP) & Cell wall production inhibition & CDAD completed (Nanotherapeutics) \\
\hline$\overline{\mathrm{TP}-434(31)^{163,164}}$ & Tetracycline (NP) & Protein synthesis inhibition & clAl (Tetraphase) \\
\hline Solithromycin (32) (CEM-101) $165-168$ & Erythromycin (NP) & Protein synthesis inhibition & CABP (Cempra) \\
\hline CXA-101 (33) (FR264205) $169-171$ & Cephalosporin (NP) & Penicillin-binding protein & clAl (Cubist) \\
\hline GSK1322322 (34) $)^{60-64}$ & Actinonin (49) (NP) & Peptide deformylase & cSSSi completed (GSK) \\
\hline PMX-30063 & Defensin (NP) & Bacterial cell membrane lysis & ABSSSi (PolyMedix) \\
\hline$\overline{N V C-422(35)^{75-78}}$ & $N$-chlorotaurine (NP) & Oxidation & $\begin{array}{l}\text { Ophthalmic, impetigo, urinary catheter blockade } \\
\text { and encrustation (Alcon/Galderma/Novabay) }\end{array}$ \\
\hline ACT-179811 172 & Unknown & Unknown & CDAD (Actelion) \\
\hline Bedaquiline (36) (TMC207, R207910) 87,89-94 & Diarylquinoline (S) & $\begin{array}{l}\text { FO subunit of mycobacterial } \\
\text { ATP synthase }\end{array}$ & TB (Tibotec/Global Alliance for TB Drug Development) \\
\hline SQ109 (37) $173-175$ & Ethambutol (S) & Cell wall synthesis & TB, H. pylori associated duodenal ulcer (Sequella) \\
\hline OPC-67683 (38) ${ }^{176,177}$ & Nitroimidazole (S) & Mycolic acid inhibitor & TB (Otsuka Pharmaceutical) \\
\hline PA-824 (39) ${ }^{178-181}$ & Nitroimidazole (S) & DNA and cellular damage & TB (Global Alliance for TB Drug Development) \\
\hline Delafloxacin (40) (RX-3341, ABT-492) $182-184$ & Fluoroquinolone (S) & DNA gyrase and topolV & cSSSi completed (Rib-X) \\
\hline Finafloxacin (41) (BAY 35-3377) 185,186 & Fluoroquinolone (S) & DNA gyrase and topolV & H. pylori and UTI completed (MerLion) \\
\hline JNJ-32729463 (42) (JNJ-Q2) $)^{187,188}$ & Fluoroquinolone (S) & DNA gyrase and topolV & CABP, cSSSi (Furiex) \\
\hline Zabofloxacin (43) (PB-101, DW-224a) ${ }^{189,190}$ & Fluoroquinolone (S) & DNA gyrase and topolV & CAP (IASO Pharma/Dong Wha) \\
\hline Nemonoxacin (44) (TG-873870) $191-194$ & Quinolone (S) & DNA gyrase and topolV & $\begin{array}{l}\text { CAP, diabetic foot infection completed } \\
\text { (TaiGen/Warner Chilcott) }\end{array}$ \\
\hline Iclaprim (45) (AR-100, Ro 48-2622) & Trimethoprim (S) & Dihydrofolate reductase & HAP, cSSSi completed (Acino Holding) \\
\hline Radezolid (46) (RX-1741) & Oxazolidinone (S) & Protein synthesis inhibition & uSSSI, CAP completed (Rib-X) \\
\hline
\end{tabular}




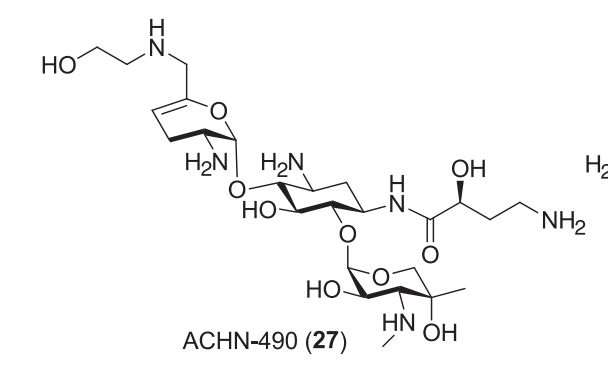

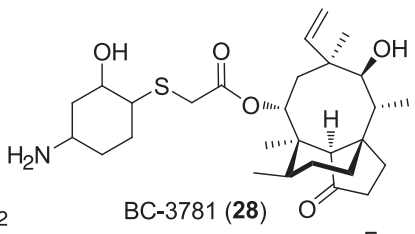

BC-3781 (28)<smiles>CN(C)[C@H]1C(O)=C(C(N)=O)C(=O)[C@]2(O)C(O)=C3C(=O)c4c(O)c(NC(=O)CN5CCCC5)cc(F)c4CC3C[C@H]12</smiles>

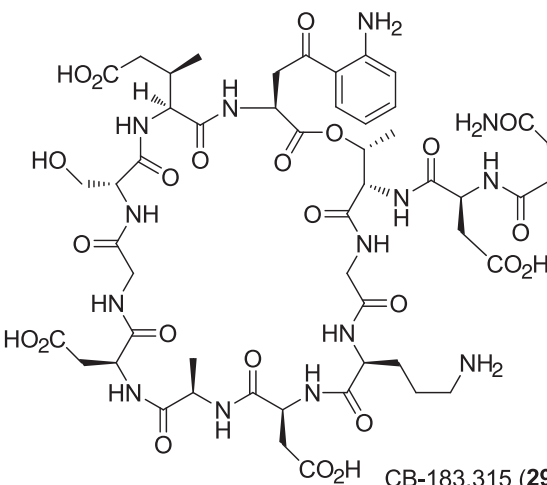

TP-434 (31)<smiles>CCCCCc1ccc(/C(C)=C/C(=O)N[C@@H](Cc2c[nH]c3ccccc23)C(=O)NC)cc1</smiles><smiles>Cc1cccc(N)c1</smiles>

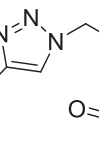

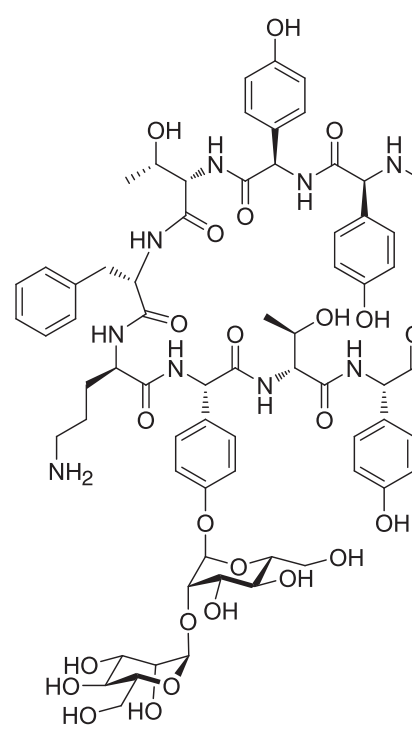

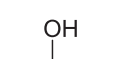<smiles>CC(=O)[C@@H](NC(=O)[C@H](CCCN)NC(=O)[C@@H](NC(=O)C(NC(=O)[C@H](CC(N)=O)NC(=O)/C=C\C=C/CC(C)C)C(OC(=O)C(C)C)C(N)=O)c1ccc(O)cc1)[C@@H](C)O</smiles>

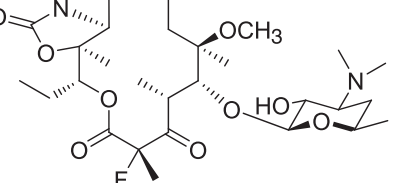

solithromycin (32)

(a) 
Table 4 Compounds in phase-I clinical trials

\begin{tabular}{|c|c|c|c|}
\hline Name (synonym) & Lead compound (source) & Mode of action & Development status, indication (Developer) \\
\hline BAL30072 (50) $203-205$ & Monobactam (NP) & Penicillin-binding protein & Dosing studies, Gram-negative (Basilea) \\
\hline BC-7013 (51) 132,206 & Pleuromutilin (NP) & Protein synthesis inhibition & Topical (Nabriva) \\
\hline BC-3205 (52) $)^{132,207}$ & Pleuromutilin (NP) & Protein synthesis inhibition & Oral (Nabriva) \\
\hline$\underline{\text { Lotilibcin }\left(W A P-8294 A_{2}\right)(53)^{95-99}}$ & WAP-8294A 2 (53) (NP) & $\begin{array}{l}\text { Phospholipid binding resulting in bacterial } \\
\text { membrane damage }\end{array}$ & i.v. formulation (MRSA) (aRigen) \\
\hline$\underline{X F-73}(54)^{100-105}$ & Porphyrin (NP) & Membrane-perturbing activity & Topical MRSA (Destiny Pharma) \\
\hline$\overline{\text { AZD97442 }} 208$ & Unknown & Unknown & $\begin{array}{l}\text { i.v. dosing and metabolism studies } \\
\text { (AstraZeneca) }\end{array}$ \\
\hline GSK2251052 (55) (AN3365) $106-112$ & AN2690 (S) & Aminoacyl-tRNA synthetase & Gram-negative systemic (GSK/ Anacor) \\
\hline$\overline{\text {AZD} 5847^{209}}$ & Oxazolidinone (S) & Protein synthesis inhibition & Dosing studies, TB (AstraZeneca) \\
\hline PNU-100480 (56) (PF-02341272)209-212 & Oxazolidinone (S) & Protein synthesis inhibition & Dosing studies, TB (Pfizer) \\
\hline AFN-1252 (57) (API-1252) & Synthetic lead $\mathbf{5 8}$ (S) & Fabl inhibition & Oral formulation, MRSA (Affinium) \\
\hline$\overline{\text { FAB-001 (59) (MUT056399)117,119 }}$ & Triclosan (60) (S) & Fabl inhibition & Entered phase-I September 2009 (FAB Pharma) \\
\hline$\overline{\mathrm{CG} 400549}(61)^{117,120-122}$ & Triclosan (60) (S) & Fabl inhibition & Dosing studies (CrystalGenomics) \\
\hline
\end{tabular}<smiles>COc1nc2ccc(Br)cc2cc1C(c1ccccc1)[C@@](O)(CCN(C)C)c1cccc2ccccc12</smiles><smiles>CC(C)=CCC/C(C)=C/CNCCNC1C2CC3CC(C2)CC1C3</smiles><smiles>CCCCCC(C)(C)Oc1ccc(N2CCC(Oc3ccc(OC[C@]4(C)Cn5cc([N+](=O)[O-])nc5O4)cc3)CC2)cc1</smiles><smiles>CC(C)(C)[R16](=O)c1cn2c(n1)OC[C@@H](OCc1ccc(OC(F)(F)F)cc1)C2</smiles><smiles>Nc1nc(-n2cc(C(=O)O)c(=O)c3cc(F)c(N4CC(O)C4)c(Cl)c32)c(F)cc1F</smiles><smiles>N#Cc1c(N2CC3NCCOC3C2)c(F)cc2c(=O)c(C(=O)O)cn(C3CC3)c12</smiles><smiles>COc1c(N2CCCC(=C(F)CN)C2)c(F)cc2c(=O)c(C(=O)O)cn(C3CC3)c12</smiles>

delafloxacin (40)<smiles>CON=C1CN(c2nc3c(cc2F)c(=O)c(C(=O)O)cn3C2CC2)CC12CNC2</smiles><smiles>COc1c(N2CC(C)C[C@@H](N)C2)ccc2c(=O)c(C(=O)O)cn(C3CC3)c12</smiles><smiles></smiles><smiles>CC(=O)NC[C@H]1CN(c2ccc(-c3ccc(CNCc4c[nH]nn4)cc3)c(F)c2)C(=O)O1</smiles>

radezolid (46)

Figure 5 Structures of synthetically derived compounds in phase-II clinical trials.

for the treatment of hospital-acquired Gram-negative infections, including Escherichia coli, Klebsiella pneumoniae and Enterobacter species. ${ }^{106,107}$ GSK2251052 (55) is a new type of protein synthesis inhibitor ${ }^{108,109}$ that binds to the active editing site of LeuRS through coordination of the Boron atom to the cis-diols of the ribose on the terminal nucleotide of $\mathrm{tRNA}^{\text {Leu }}$ GSK2251052 (55), which was 
<smiles>CC(C)(C)C(C)(C)[C@H](NC(=O)[C@H](CNC=O)CC1CCCC1)C(=O)N1CCN(Cc2ccc3c(c2)OCO3)CC1</smiles><smiles>CCCC[C@H](CN(O)C=O)C(=O)N1CCC[C@H]1C(=O)Nc1ccc(F)c[n+]1[O-]</smiles>

LBM-415 (48)<smiles>CCCCC[C@H](CC(=O)NO)C(=O)N[C@H](C(=O)N1CCC[C@H]1CO)C(C)C</smiles>

actinonin (49)

Figure 6 Structures of peptide deformylase inhibitors 47 and 48, and lead compound actinonin (49). discovered using a structure-based design approach that was initiated with a co-crystal of tRNA ${ }^{\text {Leu }}$ and AN2690, ${ }^{108-112}$ is noteworthy as being one of the first truly novel antibiotics with Gram-negative activity that has successfully completed a phase-I trial.

AFN-1252 (57) ${ }^{113,114}$ is being evaluated in a phase-I trial using an improved oral formulation by Affinium Pharmaceuticals (Austin, TX, USA), having successfully completed other phase-I trials that used single and multiple ascending doses. ${ }^{115}$ AFN-1252 (57) selectively disrupts staphylococcal bacterial fatty acid biosynthesis through inhibiting FabI, an essential enzyme that catalyzes the reduction of trans2-enoyl-ACP to acyl-ACP in the final step of the fatty acid elongation cycle. ${ }^{116,117}$ The activity of $\mathbf{5 7}$ is restricted to S. aureus, Staphylococcus epidermidis and a few other bacterial species due to the specificity and the restricted distribution of FabI. ${ }^{113,114}$ Although this narrow spectrum of activity may impart a safety advantage over conventional antibiotics that can indiscriminately kill non-pathogenic microorganisms, it will also limit the compound's use, and as a consequence, potential market size. AFN-1252 (57) is a synthetically derived antibiotic that had its genesis in a high-throughput screen undertaken at GSK that tested 305189 compounds against the S. aureus FabI and identified a benzodiazepine $\mathbf{5 8}$ with micromolar range activity. ${ }^{15,118}$ The use of a crystal structure-based design led to the discovery of the 3,4-dihydro-1,8-naphthyridin-2(1H)-one 62, which had selective, potent activity against FabI, and good in vitro and in vivo antibacterial

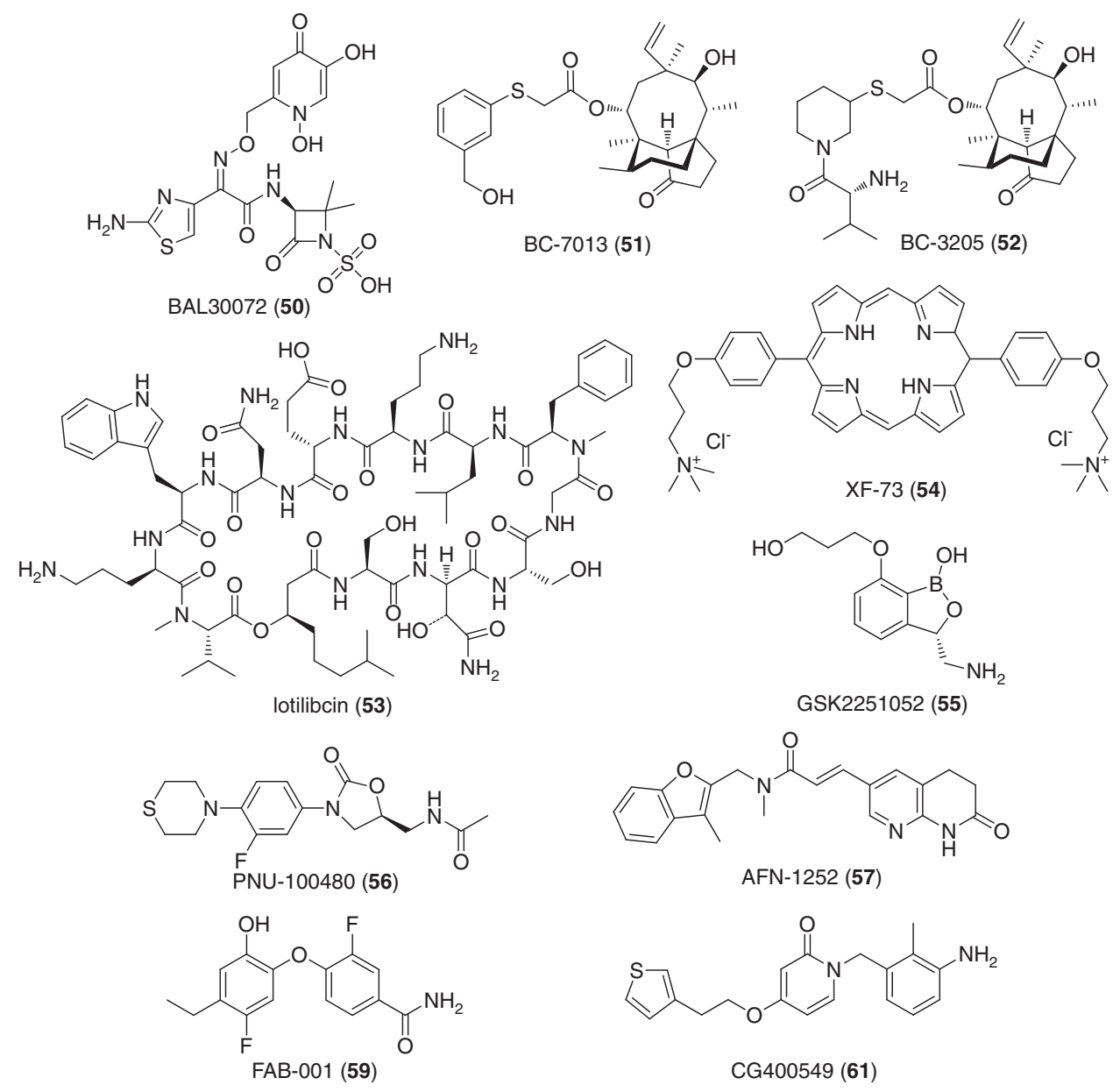

Figure 7 Structures of compounds in phase-I clinical trials. 

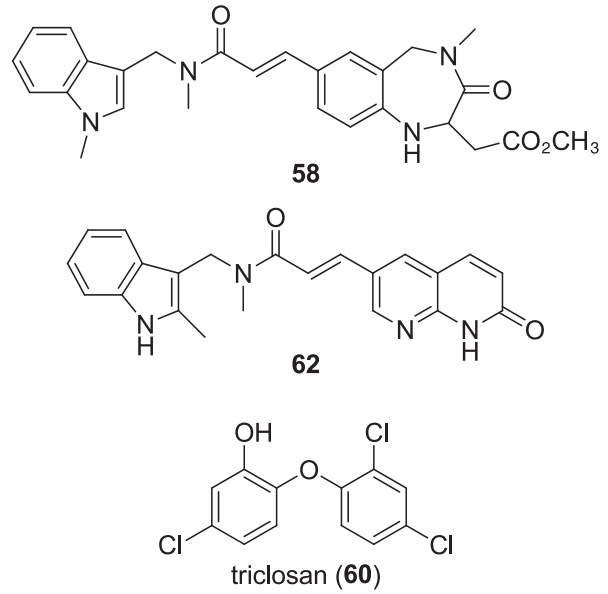

Figure 8 Structures of GSK's FabI HTS hit 59 and optimized lead 62, and triclosan (60). GSK, GlaxoSmithKline.

\section{Compounds by phase and derivation}

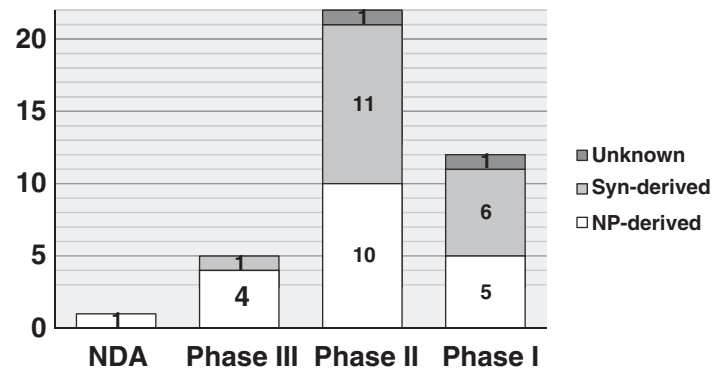

Figure 9 Compounds under clinical evaluation divided into development phases and their lead derivation source.

activity with no significant cytotoxicity. ${ }^{118}$ GSK licensed this discovery to Affinium in 2002, with further structure optimization leading to the clinical candidate AFN-1252 (57) (Figure 8). ${ }^{13,114}$

There are two further FabI inhibitors, FAB-001 (59) (MUT056399) and CG400549 (61), under clinical evaluation for the treatment of drug-resistant staphylococci whose structures were derived from triclosan (60). ${ }^{117}$ FAB Pharma (Paris, France) started a phase-I trial of FAB-001 (59) in September 2009, ${ }^{117,119}$ whereas CrystalGenomics (Seoul, Korea) have completed a single ascending-dose phase-I trial of CG400549 (61) $)^{120-122}$ and are currently studying 61 in a multiple ascending-dose phase-I trial. Triclosan (60) is a trichloro-phenoxy phenol topical antibiotic ${ }^{123-125}$ launched in the early 1970s with broad spectrum activity against a variety of Gram-positive and Gramnegative bacteria that is present in a variety of cleaning and personal care products. ${ }^{126}$ At lower concentrations, triclosan (60) was found to be bacteriostatic, and in 1999 various groups showed that this was because of FabI inhibition, ${ }^{125,127-130}$ whereas the bactericidal activity observed at high concentrations has been proposed to be caused by membrane destabilization. ${ }^{131}$

\section{ANALYSIS OF COMPOUNDS UNDERGOING CLINICAL TRIALS}

There are a total of 40 compounds currently undergoing clinical trials (Figure 9), with one being evaluated in an NDA/MAA (Table 2), five in phase-III (Table 2), 22 in phase-II (Table 3) and 12 in phase-I (Table 4). There are slightly more NP-derived compounds (20) compared with those synthetically derived (18), with two compounds of unknown derivation. The distribution between NP-derived and synthetically derived is relatively similar in phase-I and II, whereas NP-

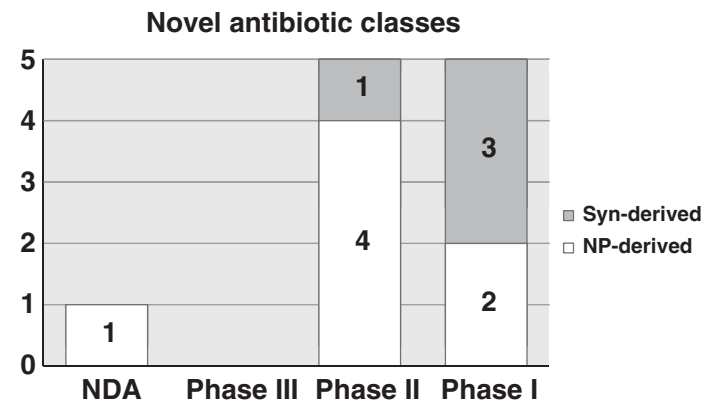

Figure 10 Compounds with new antibacterial templates divided into development phases and their lead derivation source.

derived compounds predominate in phase-III and NDA/MAA. The synthetically derived compounds classes are quite diverse (4 oxazolidinones, 1 diarylquinoline, 1 ethambutol, 2 nitroimidazole, 5 quinolones, 1 trimethoprim and 2 different types of FabI inhibitors), with strong influences from increased TB research (oxazolidinones, diarylquinoline, ethambutol and nitroimidazole) and leads from the screening of synthetic libraries combined with X-ray structure design (diarylquinoline and AFN-1252-type FabI inhibitors).

The difficulty in identifying new antibacterial templates to treat Gram-positive bacteria has been well documented. It is pleasing to note that GSK2251052 (55) represents a new antibiotic template, which is being actively pursued in clinical trials to treat various drugresistant, Gram-negative bacteria. In addition, the monobactam-siderophore hybrid BAL30072 (50), the aminoglycoside ACHN-490 (27) and various quinolones are being developed to treat Gram-negative bacteria. GSK1322322 (34), NVP-422 (35), iclaprim (45), XF-73 (54), PMX-30063 and selected oxazolidinones have also been reported to have in vitro activity against Gram-negative bacteria.

There are also more NP-derivative new antibiotic templates (7) compared with those synthetically derived (4) (Figure 10). It must be noted, however, that three of the NP-derived lead compound templates (porphyrin, $N$-chlorotaurine and defensin) are not classic secondary metabolites, as is the case with the actinomycetes-derived fidaxomicin (21), ramoplanin (30) and actinonin (49), and the bacterial-derived lotilibcin (53).

The predominance of NP-derived compounds in late-stage trials (Table 2; Figure 10) and the lack of recently launched antibiotics outside the quinolones (Table 1) is rather striking. Whether this predominance is biased by historical screening methods, or a hint that NP-derived compounds (outside of the quinolones) are more likely to prove efficacious and safe in late-stage clinical trials, is a key question. We will need to observe the progress of compounds through the clinical pipeline in the years to come, while continuing to promote scientific, regulatory and economic mechanisms to promote antibiotic discovery, development, approval, stewardship and appropriate use in the market.

\section{ACKNOWLEDGEMENTS}

This paper was prepared with the support of NHMRC Grant AF 511105.

1 Shlaes, D. M. Antibiotics: the Perfect Storm (Springer: the Netherlands, 2010).

2 Walsh, C. Antibiotics: Actions, Origins, Resistance (ASM Press: Washington, DC, USA, 2003).

3 Butler, M. S. \& Buss, A. D. Natural products-the future scaffolds for novel antibiotics? Biochem. Pharmacol. 71, 919-929 (2006).

4 Projan, S. J. Whither antibacterial drug discovery? Drug Discov. Today 13, 279-280 (2008). 
5 Silver, L. L. A retrospective on the failures and successes of antibacterial drug discovery. IDrugs 8, 651-655 (2005)

6 Rice, L. B. Federal funding for the study of antimicrobial resistance in nosocomial pathogens: no ESKAPE. J. Infect. Dis. 197, 1079-1081 (2008).

7 Talbot, G. H. What is in the pipeline for Gram-negative pathogens? Expert Rev. Anti Infect. Ther. 6, 39-49 (2008).

8 Vergidis, P. I. \& Falagas, M. E. New antibiotic agents for bloodstream infections. Int. J. Antimicrob. Agents 32, S60-S65 (2008).

9 Livermore, D. M. Has the era of untreatable infections arrived? J. Antimicrob. Chemother. 64, i29-i36 (2009).

10 Boucher, H. W. Challenges in anti-infective development in the era of bad bugs, no drugs: a regulatory perspective using the example of bloodstream infection as an indication. Clin. Infect. Dis. 50, S4-S9 (2010).

11 Trémolières, F., Cohen, R., Gauzit, R., Vittecoq, D. \& Stahl, J. P. Save antibiotics! What can be done to prevent a forecasted disaster? Suggestions to promote the development of new antibiotics. Réanimation 19, 354-360 (2010).

12 Moellering, R. C. The problem of complicated skin and skin structure infections: the need for new agents. J. Antimicrob. Chemother. 65, iv3-iv8 (2010).

13 Hamad, B. The antibiotics market. Nat. Rev. Drug Discov. 9, 675-676 (2010).

14 Gwynn, M. N., Portnoy, A., Rittenhouse, S. F. \& Payne, D. J. Challenges of antibacterial discovery revisited. Ann. N. Y. Acad. Sci. 1213, 5-19 (2010).

15 Payne, D. J., Gwynn, M. N., Holmes, D. J. \& Pompliano, D. L. Drugs for bad bugs: confronting the challenges of antibacterial discovery. Nat. Rev. Drug Discov. 6, 29-40 (2007).

16 Morel, C. M. \& Mossialos, E. Stoking the antibiotic pipeline. BMJ 340, 1115-1118 (2010)

17 Jones, D. The antibacterial lead discovery challenge. Nat. Rev. Drug Discov. 9, 751-752 (2010).

18 Moellering, R. C. Jr Discovering new antimicrobial agents. Int. J. Antimicrob. Agents 37, 2-9 (2011).

19 Jones, D. A guiding hand for antibiotics. Nat. Rev. Drug Discov. 10, 161-162 (2011).

20 Silver, L. L. Challenges of antibacterial discovery. Clin. Microbiol. Rev. 24, 71-109 (2011).

21 Infectious Diseases Society of America. The 10×'20 Initiative: pursuing a global commitment to develop 10 new antibacterial drugs by 2020. Clin. Infect. Dis. 50, 1081-1083 (2010).

22 Spellberg, B. Antibiotic Resistance: Promoting Critically Needed Antibiotic Research and Development and Appropriate Use ('Stewardship') of these Precious Drugs Infectious Diseases Society of America <http://www.idsociety.org/WorkArea/Download Asset.aspx?id=16656> (2010, accessed 4 April 2011).

23 Boucher, H. W. et al. Bad bugs, no drugs: no ESKAPE! An update from the infectious diseases society of America. Clin. Infect. Dis. 48, 1-12 (2009).

24 European Centre for Disease Prevention and Control/European Medicines Agency. European Centre for Disease Prevention and Control/European Medicines Agency Joint Technical Report. the Bacterial Challenge: Time to React <http://www.emea. europa.eu/pdfs/human/antimicrobial_resistance/EMEA-576176-2009.pdf $\rangle$ (2009, accessed 4 April 2011)

25 O'Shea, R. \& Moser, H. E. Physicochemical properties of antibacterial compounds: implications for drug discovery. J. Med. Chem. 51, 2871-2878 (2008).

26 Silver, L. L. Are natural products still the best source for antibacterial discovery? The bacterial entry factor. Expert Opin. Drug Discov. 3, 487-500 (2008).

27 Optimer Pharmaceuticals. Optimer Pharmaceuticals Completes New Drug Application for Fidaxomicin and Requests Priority Review from FDA (press release 18 November 2010) 〈http://www.optimerpharma.com/news.asp > (2010).

28 Optimer Pharmaceuticals. The New England Journal of Medicine Publishes Results of Fidaxomicin Phase 3 Trial Showing Significantly Lower Recurrence Rates and Improved Global Cure Rates Compared to Vancomycin in Patients with Clostridium difficile Infection (CDI) (press release 2 February 2011) < http://www.optimerpharma. com/news.asp $>$ (2011).

29 Norén, T. in Clostridium difficile. Methods in Molecular Biology. Vol. 646 (eds Mullany, P. and Roberts, A.P.) 9-35 (Humana Press: Totowa, NJ, USA, 2010).

30 Bartlett, J. G. Clostridium difficile: progress and challenges. Ann. N. Y. Acad. Sci. 1213, 62-69 (2010).

31 Cartman, S. T., Heap, J. T., Kuehne, S. A., Cockayne, A. \& Minton, N. P. The emergence of 'hypervirulence' in Clostridium difficile. Int. J. Med. Microbiol. 300, 387-395 (2010).

32 Johnson, A. P. New antibiotics for selective treatment of gastrointestinal infection caused by Clostridium difficile. Expert Opin. Ther. Pat. 20, 1389-1399 (2010).

33 Trial watch: phase III success for novel Clostridium difficile antibiotic. Nat. Rev. Drug Discov. 9, 260 (2010).

34 Louie, T., Miller, M., Donskey, C., Mullane, K. \& Goldstein, E. J. C. Clinical outcomes, safety, and pharmacokinetics of OPT-80 in a phase 2 trial with patients with Clostridium difficile infection. Antimicrob. Agents Chemother. 53, 223-228 (2009).

35 McAlpine, J. B., Jackson, M., Karwowski, J., Theriault, R. J. \& Hochlowski, J. (Abbott Laboratories) Tiacumicin compounds. US 4,918,174, April 17 (1990).

36 Hochlowski, J. E. et al. Tiacumicins, a novel complex of 18-membered macrolides. II. Isolation and structure determination. J. Antibiot. 40, 575-588 (1987).

37 Theriault, R. J. et al. Tiacumicins, a novel complex of 18-membered macrolide antibiotics. I. Taxonomy, fermentation and antibacterial activity. J. Antibiot. 40, 567-574 (1987).

38 Coronelli, C., White, R. J., Lancini, G. C. \& Parenti, F. Lipiarmycin, a new antibiotic from Actinoplanes. II. Isolation, chemical, biological, and biochemical characterization. J. Antibiot. 28, 253-259 (1975).
39 Coronelli, C., Parenti, F., White, R. \& Pagani, H. (Gruppo Lepetit S.p.A.) Lipiarmycin and its preparation. US 3,978,211, August 31 (1976).

40 Parenti, F., Pagani, H. \& Beretta, G. Lipiarmycin, a new antibiotic from Actinoplanes. I. Description of the producer strain and fermentation studies. J. Antibiot. 28, 247-252 (1975)

41 Sergio, S., Pirali, G., White, R. \& Parenti, F. Lipiarmycin, a new antibiotic from Actinoplanes. III. Mechanism of action. J. Antibiot. 28, 543-549 (1975).

42 Arnone, A., Nasini, G. \& Cavalleri, B. Structure elucidation of the macrocyclic antibiotic lipiarmycin. J. Chem. Soc. Perkin Trans. 1, 1353-1359 (1987).

43 Cavalleri, B., Arnone, A., Di, M. E., Nasini, G. \& Goldstein, B. P. Structure and biological activity of lipiarmycin B. J. Antibiot. 41, 308-315 (1988).

44 Omura, S. et al. Clostomicins, new antibiotics produced by Micromonospora echinospora subsp. armeniaca subsp. nov. I. Production, isolation, and physicochemical and biological properties. J. Antibiot. 39, 1407-1412 (1986).

45 Talpaert, M., Campagnari, F. \& Clerici, L. Lipiarmycin, an antibiotic inhibiting nucleic acid polymerases. Biochem. Biophys. Res. Commun. 63, 328-334 (1975).

46 Sonenshein, A. L. \& Alexander, H. B. Initiation of transcription in vitro is inhibited by lipiarmycin. J. Mol. Biol. 127, 55-72 (1979).

47 Sonenshein, A. L., Alexander, H. B., Rothstein, D. B. \& Fisher, S. H. Lipiarmycinresistant ribonucleic acid polymerase mutants of Bacillus subtilis. J. Bacteriol. 132, 73-79 (1977).

48 Tupin, A., Gualtieri, M., Leonetti, J.- P. \& Brodolin, K. The transcription inhibitor lipiarmycin blocks DNA fitting into the RNA polymerase catalytic site. EMBO J. 29, 2527-2537 (2010)

49 Kurabachew, M. et al. Lipiarmycin targets RNA polymerase and has good activity against multidrug-resistant strains of Mycobacterium tuberculosis. J. Antimicrob. Chemother. 62, 713-719 (2008).

50 Nanotherapeutics. Nanotherapeutics Acquires Two Late Stage Clinical Programs for Alzheimer's Treatment and CDA Disease (press release 16 December 2009) <http:// www.nanotherapeutics.com/news_press_releases.php $>$ (2009).

51 Cavalleri, B., Pagani, H., Volpe, G., Selva, E. \& Parenti, F. A-16686, a new antibiotic from Actinoplanes. I. Fermentation, isolation and preliminary physico-chemical characteristics. J. Antibiot. 37, 309-317 (1984).

52 Pallanza, R., Berti, M., Scotti, R., Randisi, E. \& Arioli, V. A-16686, a new antibiotic from Actinoplanes. II. Biological properties. J. Antibiot. 37, 318-324 (1984).

53 Ciabatti, R. et al. Ramoplanin (A-16686), a new glycolipodepsipeptide antibiotic. III. Structure elucidation. J. Antibiot. 42, 254-267 (1989).

54 Skelton, N. J. et al. Structure elucidation and solution conformation of the glycopeptide antibiotic ramoplanose (UK-71,903): a cyclic depsipeptide containing an antiparallel $\beta$-sheet and a $\beta$-bulge. J. Am. Chem. Soc. 113, 7522-7530 (1991)

55 Kettenring, J. K., Ciabatti, R., Winters, G., Tamborini, G. \& Cavalleri, B. Ramoplanin (A-16686), a new glycolipodepsipeptide antibiotic. IV. Complete sequence determination by homonuclear 2D NMR spectroscopy. J. Antibiot. 42, 268-275 (1989).

56 Fang, X. et al. The mechanism of action of ramoplanin and enduracidin. Mol. BioSyst. 2, 69-76 (2006).

57 Breukink, E. \& de Kruijff, B. Lipid II as a target for antibiotics. Nat. Rev. Drug Discov. 5, 321-323 (2006).

58 Schneider, T. \& Sahl, H.- G. Lipid II and other bactoprenol-bound cell wall precursors as drug targets. Curr. Opin. Invest. Drugs 11, 157-164 (2010).

59 Hamburger, J. B. et al. A crystal structure of a dimer of the antibiotic ramoplanin illustrates membrane positioning and a potential lipid II docking interface. Proc. Natl. Acad. Sci. USA 106, 13759-13764 (2009).

60 Singley, C., Hoover, J., DeMarsh, P., Elefante, P. \& Zalacain, M. Efficacy of PDF inhibitor GSK1322322 against abscess infections caused by MRSA using a computer-controlled infusion system to recreate human PK profiles in rats. 50th Interscience Conference on Antimicrobial Agents and Chemotherapy Conference (Boston, MA), Poster F1-2114 (2010).

61 Lewandowski, T., Demarsh, P., Peters, T. \& Kulkarni, S. Potent activity of GSK1322322 a novel peptide deformylase inhibitor after oral dosing in a murine multi-drug resistant Staphylococcus aureus infection. 50th Interscience Conference on Antimicrobial Agents and Chemotherapy Conference (Boston, MA), Poster F12113 (2010).

62 Bouchillon, S., Hackel, M., Hoban, D., Zalacain, M. \& Butler, D. In vitro activity of GSK1322322, a novel peptide deformylase inhibitor, against 4836 pathogens from skin and soft tissue infections and respiratory tract infections. 50th Interscience Conference on Antimicrobial Agents and Chemotherapy Conference (Boston, MA), Poster F1-2112 (2010).

63 Lewandowski, T., Demarsh, P., Peters, T. \& Kulkarni, S. Potent Activity of GSK1322322 a novel peptide deformylase inhibitor after oral dosing in a murine multi-drug resistant Staphylococcus aureus infection. 50th Interscience Conference on Antimicrobial Agents and Chemotherapy Conference (Boston, MA), Poster F1-2113 (2010)

64 US National Institutes of Health. A GSK1322322 versus Linezolid in the Treatment of Acute Bacterial Skin and Skin Structure Infection (NCT01209078) US National Institutes of Health 〈http://clinicaltrials.gov/ct2/show/NCT01209078〉 (accessed 4 April 2011)

65 Sharma, A., Khuller, G. K. \& Sharma, S. Peptide deformylase-a promising therapeutic target for tuberculosis and antibacterial drug discovery. Expert Opin. Ther. Targets 13, 753-765 (2009)

66 Leeds, J. A. \& Dean, C. R. Peptide deformylase as an antibacterial target: a critical assessment. Curr. Opin. Pharmacol. 6, 445-452 (2006). 
67 Azoulay-Dupuis, E., Mohler, J. \& Bedos, J. P. Efficacy of BB-83698, a novel peptide deformylase inhibitor, in a mouse model of pneumococcal pneumonia. Antimicrob. Agents Chemother. 48, 80-85 (2004).

68 Osborne, C. S. et al. In vivo characterization of the peptide deformylase inhibitor LBM415 in murine infection models. Antimicrob. Agents Chemother. 53, 3777-3781 (2009).

69 Waites, K. B., Reddy, N. B., Crabb, D. M. \& Duffy, L. B. Comparative in vitro activities of investigational peptide deformylase inhibitor NVP LBM-415 and other agents against human mycoplasmas and ureaplasmas. Antimicrob. Agents Chemother. 49, 2541-2542 (2005).

70 Gordon, J. J., Kelly, B. K. \& Miller, G. A. Actinonin: an antibiotic substance produced by an actinomycete. Nature 195, 701-702 (1962).

71 Gordon, J. J. et al. Studies concerning the antibiotic actinonin. Part I. The constitution of actinonin. A natural hydroxamic acid with antibiotic activity. J. Chem. Soc., Perkin Trans. 1, 819-825 (1975).

72 Chen, D. Z. et al. Actinonin, a naturally occurring antibacterial agent, is a potent deformylase inhibitor. Biochemistry 39, 1256-1262 (2000).

73 US National Institutes of Health. Study to Evaluate NVC-422 for Urinary Catheter Blockage and Encrustation (NCTO1243125) US National Institutes of Health 〈http://clinicaltrials.gov/ct2/show/NCT01243125〉 (accessed 4 April 2011).

74 NovaBay Pharmaceuticals. NovaBay Pharmaceuticals Provides Summary of 2010 Accomplishments and 2011 Outlook. (press release 2 February 2011) (http:// www.novabaypharma.com/investors/release/Feb_2_2011>(2011).

75 Shiau, T. P. et al. Stieglitz rearrangement of $N, N$-dichloro- $\beta, \beta$-disubstituted taurines under mild aqueous conditions. Bioorg. Med. Chem. Lett. 19, 1110-1114 (2009).

76 Francavilla, C. et al. Quaternary ammonium $N, N$-dichloroamines as topical, antimicrobial agents. Bioorg. Med. Chem. Lett. 19, 2731-2734 (2009).

77 Wang, L., Khosrovi, B. \& Najafi, R. N-Chloro-2,2-dimethyltaurines: a new class of remarkably stable $N$-chlorotaurines. Tetrahedron Lett. 49, 2193-2195 (2008).

78 Gottardi, W. \& Nagl, M. N-chlorotaurine, a natural antiseptic with outstanding tolerability. J. Antimicrob. Chemother. 65, 399-409 (2010).

79 Zgliczyñski, J. M., Stelmaszyñsky, T., Domañski, J. \& Ostrowski, W. Chloramines as intermediates of oxidation reaction of amino acids by myeloperoxidase. Biochim. Biophys. Acta Enzymol. 235, 419-424 (1971).

80 Stelmaszyñsky, T. \& Zgliczyñski, J. M. Myeloperoxidase of human neutrophilic granulocytes as chlorinating enzyme. Eur. J. Biochem. 45, 305-312 (1974).

81 PolyMedix. PolyMedix Successfully Completes Phase 1 Exposure Escalation Safety Study with PMX-30063 Antibiotic (press release 24 February 2011) 〈http://www. polymedix.com/ $>$ (2011).

82 PolyMedix. PMX-30063 Antibiotic Fact Sheet (February 2011) <http://www. polymedix. com/pdf/PMX-30063factsheet.pdf $>$ (accessed 4 April 2011).

83 Liu, D. et al. Nontoxic membrane-active antimicrobial arylamide oligomers. Angew. Chem. Int. Ed. 43, 1158-1162 (2004).

84 Choi, S. et al. De novo design and in vivo activity of conformationally restrained antimicrobial arylamide foldamers. Proc. Natl. Acad. Sci. USA 106, 6968-6973 (2009).

85 Scott, R. W. Defensin mimetics: nature knows best. Am. Biotechnol. Lab. 27, 16-19 (2009).

86 Tew, G. N., Scott, R. W., Klein, M. L. \& DeGrado, W. F. De novo design of antimicrobial polymers, foldamers, and small molecules: from discovery to practical applications. Acc. Chem. Res. 43, 30-39 (2010).

87 Webb, S. Public-private partnership tackles TB challenges in parallel. Nat. Rev. Drug Discov. 8, 599-600 (2009).

88 Tibotec. Unique Collaboration between TB Alliance and Tibotec to Accelerate Tuberculosis Drug Development (press release 17 June 2009) 〈http://www.tibotec.com/ news/detail.jhtml?action=view\&itemname $=$ news 62 $>$ (2009).

89 Diacon, A. H. et al. The diarylquinoline TMC207 for multidrug-resistant tuberculosis. N. Engl. J. Med. 360, 2397-2405 (2009).

90 Rustomjee, R. et al. Early bactericidal activity and pharmacokinetics of the diarylquinoline TMC207 in treatment of pulmonary tuberculosis. Antimicrob. Agents Chemother. 52, 2831-2835 (2008)

91 Andries, K. et al. A diarylquinoline drug active on the ATP synthase of Mycobacterium tuberculosis. Science 307, 223-227 (2005).

92 Koul, A. et al. Diarylquinolines target subunit $\mathrm{c}$ of mycobacterial ATP synthase. Nat. Chem. Biol. 3, 323-324 (2007).

93 Koul, A. et al. Diarylquinolines are bactericidal for dormant mycobacteria as a result of disturbed ATP homeostasis. J. Biol. Chem. 283, 25273-25280 (2008).

94 Haagsma, A. C. et al. Selectivity of TMC207 towards mycobacterial ATP synthase compared with that towards the eukaryotic homologue. Antimicrob. Agents Chemother. 53, 1290-1292 (2009).

95 aRigen Pharmaceutical. WAP-8294A2 (Lotilibcin), a First-line Anti-MRSA Product Candidate: License Agreement Boosts Development of Novel Therapy Against MRSA Infection (aRigen press release 21 January 2011) (http://www.arigen.jp/main/ newsPR.htm> (2011).

96 Harada, K. et al. Separation of WAP-8294A components, a novel anti-methicillinresistant Staphylococcus aureus antibiotic, using high-speed counter-current chromatography. J. Chromatogr. A 932, 75-81 (2001).

97 Ohashi, Y. et al. (Wakamoto Pharmacetical Co.) Antibiotics WAP-8294A, Method for Preparing the Same and Antibacterial Compositions. US 5,648,455 (1997).

98 Kato, A. et al. WAP-8294A , a novel anti-MRSA antibiotic produced by Lysobactersp. J. Am. Chem. Soc. 119, 6680-6681 (1997).

99 Kato, A. et al. A new anti-MRSA antibiotic complex, WAP-8294A I. Taxonomy, isolation and biological activities. J. Antibiot. 51, 929-935 (1998).
100 Destiny Pharma. Destiny Pharma present XF-73 Clinical Results at the 50th Annual ICAAC Meeting in Boston, USA (press release September 2010) < http://www.destinypharma.com/news current.shtml $>$ (2010, accessed 4 April 2011).

101 Maisch, T., Bosl, C., Szeimies, R. M., Lehn, N. \& Abels, C. Photodynamic effects of novel XF porphyrin derivatives on prokaryotic and eukaryotic cells. Antimicrob. Agents Chemother. 49, 1542-1552 (2005).

102 Farrell, D. J., Robbins, M., Rhys-Williams, W. \& Love, W. G. In vitro activity of XF-73, a novel antibacterial agent, against antibiotic-sensitive and -resistant Gram-positive and Gram-negative bacterial species. Int. J. Antimicrob. Agents 35, 531-536 (2010).

103 Ooi, N. et al. XF-73, a novel antistaphylococcal membrane-active agent with rapid bactericidal activity. J. Antimicrob. Chemother. 64, 735-740 (2009).

104 Ooi, N. et al. XF-70 and XF-73, novel antibacterial agents active against slow-growing and non-dividing cultures of Staphylococcus aureus including biofilms. J. Antimicrob. Chemother. 65, 72-78 (2010).

105 Farrell, D. J., Robbins, M., Rhys-Williams, W. \& Love, W. G. Investigation of the potential for mutational resistance to XF-73, retapamulin, mupirocin, fusidic acid, daptomycin, and vancomycin in methicillin-resistant Staphylococcus aureus Isolates during a 55-passage study. Antimicrob. Agents Chemother. 55, 1177-1181 (2011).

106 US National Institutes of Health. An Open-Label, Randomized, Single Period, Parallel-Cohort Study to Evaluate Serum and Pulmonary Pharmacokinetics Following Single and Multiple Dose Administration of Intravenous GSK2251052 in Healthy Adult Subjects (NCTO1267968) US National Institutes of Health <http://clinicaltrials. gov/ct2/show/NCT01267968> (accessed 4 April 2011).

107 US National Institutes of Health. A Randomized, Single Blind, Placebo Controlled Study to Evaluate Safety, Tolerability, and Pharmacokinetics of Single Oral Doses and Repeat Escalating Oral Doses of GSK2251052 in Healthy Adult Subjects (NCT01262885) US National Institutes of Health <http://clinicaltrials.gov/ct2/ show/NCT01262885> (accessed 4 April 2011).

108 Hernandez, V. et al. Discovery and mechanism of action of AN3365: A novel Boroncontaining antibacterial agent in clinical development for Gram-negative infections. 50th Interscience Conference on Antimicrobial Agents and Chemotherapy Conference (Boston, MA), Poster F1-1637 (2010).

109 Hernandez, V. et al. Structure-guided discovery of ABX a 3-aminomethyl benzoxaborole: a first in class antibacterial for Gram-negative bacterial infections. Keystone Symposia: Antibiotics and Resistance: Challenges and Solutions (Santa Fe, NM) (2010).

110 Baker, S. J. et al. Discovery of a new Boron-containing antifungal agent, 5-fluoro-1,3dihydro-1-hydroxy-2,1-benzoxaborole (AN2690), for the potential treatment of onychomycosis. J. Med. Chem. 49, 4447-4450 (2006).

111 Rock, F. L. et al. An antifungal agent inhibits an aminoacyl-tRNA synthetase by trapping tRNA in the editing site. Science 316, 1759-1761 (2007).

112 Seiradake, E. et al. Crystal structures of the human and fungal cytosolic leucyl-tRNA synthetase editing domains: a structural basis for the rational design of antifungal benzoxaboroles. J. Mol. Biol. 390, 196-207 (2009).

113 Karlowsky, J. A et al. In vitro activity of API-1252, a novel Fabl inhibitor, against clinical isolates of Staphylococcus aureus and Staphylococcus epidermidis. Antimicrob. Agents Chemother. 51, 1580-1581 (2007).

114 Karlowsky, J. A., Kaplan, N., Hafkin, B., Hoban, D. J. \& Zhanel, G. G. AFN-1252, a Fabl inhibitor, demonstrates a Staphylococcus-specific spectrum of activity. Antimicrob. Agents Chemother. 53, 3544-3548 (2009).

115 Affinium Pharmaceuticals. Affinium Pharmaceuticals Programs Overview <http:// www.afnm.com/programs/ $>$ (accessed 4 April 2011).

$116 \mathrm{Lu}, \mathrm{H}$. \& Tonge, P. J. Inhibitors of Fabl, an enzyme drug target in the bacterial fatty acid biosynthesis pathway. Acc. Chem. Res. 41, 11-20 (2008).

117 Gerusz, V. in Annual Reports in Medicinal Chemistry Vol. 45 (ed Macor, E.J.) 295-311 (Academic Press: Burlington, MA, USA, 2010).

118 Payne, D. J. et al. Discovery of a novel and potent class of Fabl-directed antibacterial agents. Antimicrob. Agents Chemother. 46, 3118-3124 (2002).

119 Medical News Today. FAB Pharma, a Biopharma Company Developing Drugs To Treat Severe Bacterial Infections 〈http://www.medicalnewstoday.com/articles/164032.php > (2009, accessed 4 April 2011).

120 Yum, J. H. et al. In vitro activities of CG400549, a novel Fabl inhibitor, against recently isolated clinical staphylococcal strains in Korea. Antimicrob. Agents Chemother. 51, 2591-2593 (2007).

121 Park, H. S. et al. Antistaphylococcal activities of CG400549, a new bacterial enoyl-acyl carrier protein reductase (Fabl) inhibitor. J. Antimicrob. Chemother. 60, 568-574 (2007)

122 Bogdanovich, T. et al. Antistaphylococcal activity of CG400549, a new experimental Fabl inhibitor, compared with that of other agents. Antimicrob. Agents Chemother. 51, 4191-4195 (2007)

123 Jungermann, E. \& Taber, D. A new broad spectrum antibacterial soap I. General properties. J. Am. Oil Chem. Soc. 48, 318-323 (1971).

124 Russell, A. D. Whither triclosan? J. Antimicrob. Chemother. 53, 693-695 (2004).

125 Saleh, S., Haddadin, R. N. S., Baillie, S. \& Collier, P. J. Triclosan-an update. Lett. Appl. Microbiol. 52, 87-95 (2011).

126 US Department of Health \& Human Services. Ingredients: Triclosan, Household Products Database <http://householdproducts.nlm.nih.gov/cgi-bin/household/brands? $\mathrm{tbl}=\mathrm{chem \& id}=201>($ accessed 4 April 2011).

127 Ward, W. H. J. et al. Kinetic and structural characteristics of the inhibition of enoyl (acyl carrier protein) reductase by triclosan. Biochemistry 38, 12514-12525 (1999).

128 Stewart, M. J., Parikh, S., Xiao, G., Tonge, P. J. \& Kisker, C. Structural basis and mechanism of enoyl reductase inhibition by triclosan. J. Mol. Biol. 290, 859-865 (1999). 
129 Levy, C. W. et al. Molecular basis of triclosan activity. Nature 398, 383-384 (1999). $130 \mathrm{Xu}, \mathrm{H}$. et al. Mechanism and inhibition of saFabl, the enoyl reductase from Staphylococcus aureus. Biochemistry 47, 4228-4236 (2008).

131 Gomez Escalada, M., Russell, A. D., Maillard, J. Y. \& Ochs, D. Triclosan-bacteria interactions: single or multiple target sites? Lett. Appl. Microbiol. 41, 476-481 (2005).

132 Novak, R. \& Shlaes, D. M. The pleuromutilin antibiotics: a new class for human use. Curr. Opin. Invest. Drugs 11, 182-191 (2010).

133 Wang, J. et al. A phase II study of antofloxacin hydrochloride, a novel fluoroquinolone, for the treatment of acute bacterial infections. Chemotherapy 56, 378-385 (2010).

134 Wang, J. et al. Pharmacokinetics of antofloxacin hydrochloride, a novel fluoroquinolone, after single-dose intravenous administration in healthy Chinese male volunteers. Xenobiotica 40, 344-349 (2010).

135 Shanghai Institute of Materia Medica. Antofloxacin Hydrochloride and its Tablets, a Class One New Drug, has been Granted New Drug License and Drug Approval Certificate (press release 23 June 2009) <http://english.simm.cas.cn/rp/200906/ t20090626_9128.html > (2009, accessed 4 April 2011).

136 Chung, J. Y. L., Hartner, F. W. \& Cvetovich, R. J. Synthesis development of an aminomethylcycline antibiotic via an electronically tuned acyliminium Friedel-Crafts reaction. Tetrahedron Lett. 49, 6095-6100 (2008).

137 Wang, Y., Castaner, R., Bolos, J. \& Estivill, C. Amadacycline: tetracycline antibiotic. Drugs Future 34, 11-15 (2009).

$138 \mathrm{Im}$, W. B. et al. Discovery of torezolid as a novel 5-hydroxymethyl-oxazolidinone antibacterial agent. Eur. J. Med. Chem. 46, 1027-1039 (2011).

139 Brown, S. D. \& Traczewski, M. M. Comparative in vitro antimicrobial activities of torezolid (TR-700), the active moiety of a new oxazolidinone, torezolid phosphate (TR701), determination of tentative disk diffusion interpretive criteria, and quality control ranges. Antimicrob. Agents Chemother. 54, 2063-2069 (2010).

140 Prokocimer, P. et al. Phase 2, randomized, double-blind, dose-ranging study evaluating the safety, tolerability, population pharmacokinetics, and efficacy of oral torezolid phosphate in patients with complicated skin and skin structure infections. Antimicrob. Agents Chemother. 55, 583-592 (2011).

141 Cooper, R. D. G. et al. Reductive alkylation of glycopeptide antibiotics: synthesis and antibacterial activity. J. Antibiot. 49, 575-581 (1996).

142 Bouza, E. \& Burillo, A. Oritavancin: a novel lipoglycopeptide active against Grampositive pathogens including multiresistant strains. Int. J. Antimicrob. Agents 36, 401-407 (2010).

143 Belley, A. et al. Oritavancin disrupts membrane integrity of Staphylococcus aureus and vancomycin-resistant enterococci to effect rapid bacterial killing. Antimicrob. Agents Chemother. 54, 5369-5371 (2010).

144 Allen, N. E. From vancomycin to oritavancin: the discovery and development of a novel lipoglycopeptide antibiotic. Anti-Infect. Agents Med. Chem. 9, 23-47 (2010).

145 Guskey, M. T. \& Tsuji, B. T. A comparative review of the lipoglycopeptides: oritavancin, dalbavancin, and telavancin. Pharmacotherapy 30, 80-94 (2010).

146 Malabarba, A. et al. Amides of de-acetylglucosaminyl-deoxy teicoplanin active against highly glycopeptide-resistant enterococci. Synthesis and antibacterial activity. J. Antibiot. 47, 1493-1506 (1994).

147 Malabarba, A. \& Goldstein, B. P. Origin, structure, and activity in vitro and in vivo of dalbavancin. J. Antimicrob. Chemother. 55, ii15-ii20 (2005).

148 Biedenbach, D. J., Bell, J. M., Sader, H. S., Turnidge, J. D. \& Jones, R. N. Activities of dalbavancin against a worldwide collection of $81673 \mathrm{Gram}$-positive bacterial isolates. Antimicrob. Agents Chemother. 53, 1260-1263 (2009).

149 Sosio, M., Canavesi, A., Stinchi, S. \& Donadio, S. Improved production of A40926 by Nonomuraea sp. through deletion of a pathway-specific acetyltransferase. Appl. Microbiol. Biotechnol. 87, 1633-1638 (2010).

150 Or, Y. S. et al. Design, synthesis, and antimicrobial activity of 6-O-substituted ketolides active against resistant respiratory tract pathogens. J. Med. Chem. 43, 1045-1049 (2000)

$151 \mathrm{Ma}, \mathrm{Z}$. et al. Novel erythromycin derivatives with aryl groups tethered to the C-6 position are potent protein synthesis inhibitors and active against multidrug-resistant respiratory pathogens. J. Med. Chem. 44, 4137-4156 (2001).

152 Hammerschlag, M. R. \& Sharma, R. Use of cethromycin, a new ketolide, for treatment of community-acquired respiratory infections. Expert Opin. Invest. Drugs 17, 387-400 (2008)

153 Rafie, S., MacDougall, C. \& James, C. L. Cethromycin: a promising new ketolide antibiotic for respiratory infections. Pharmacotherapy 30, 290-303 (2010).

154 Zeitlinger, M., Wagner, C. C. \& Heinisch, B. Ketolides-the modern relatives of macrolides: the pharmacokinetic perspective. Clin. Pharmacokinet. 48, 23-38 (2009).

155 Endimiani, A. et al. ACHN-490, a neoglycoside with potent in vitro activity against multidrug-resistant Klebsiella pneumoniae isolates. Antimicrob. Agents Chemother. 53, 4504-4507 (2009).

156 Aggen, J. B. et al. Synthesis and spectrum of the neoglycoside ACHN-490. Antimicrob. Agents Chemother. 54, 4636-4642 (2010).

157 Armstrong, E. S. \& Miller, G. H. Combating evolution with intelligent design: the neoglycoside ACHN-490. Curr. Opin. Microbiol. 13, 565-573 (2010).

158 US National Institutes of Health. Study Comparing the Safety and Efficacy of Two Doses of BC-3781 vs Vancomycin in Patients with Acute Bacterial Skin and Skin Structure Infection (ABSSSI) (NCTO1119105) <http://clinicaltrials.gov/ct2/show/ NCT01119105> (accessed 4 April 2011).

159 Sader, H. S. et al. Activity of BC-3781, a novel pleuromutilin compound, tested against clinical isolates of MRSA, including molecularly characterized community- acquired and hospital-associated strains. 50th Interscience Conference on Antimicrobial Agents and Chemotherapy Conference. (Boston, MA), Poster F1-2105 (2010).

160 Wicha, W. W., Ivezic-Schoenfeld, Z. \& Novak, R. Efficacy of BC-3781 in murine pneumonia models. 50th Interscience Conference on Antimicrobial Agents and Chemotherapy Conference. (Boston, MA), Poster F1-2107 (2010).

161 Yin, N. et al. Structure activity relationship studies of aromatic tail containing lipopeptides leading to CB-183315, a novel cyclic lipopeptide being developed for the treatment of Clostridium difficile infection. 50th Interscience Conference on Antimicrobial Agents and Chemotherapy Conference. (Boston, MA), Poster F1-1612 (2010).

162 US National Institutes of Health. Study of CB-183315 in Patients with Clostridium Difficile Infection (NCT01085591) <http://clinicaltrials.gov/ct2/show/ NCT01085591> (accessed 4 April 2011).

163 Hunt, D. et al. TP-434 is a novel broad-spectrum fluorocycline. 50th Interscience Conference on Antimicrobial Agents and Chemotherapy Conference (Boston, MA), Poster F1-2157 (2010).

164 US National Institutes of Health. Study to Compare TP-434 and Ertapenem in CA Complicated Intra-abdominal Infections (NCTO1265784) < http://clinicaltrials.gov/ ct2/show/NCT01265784> (accessed 4 April 2011).

165 McGhee, P. et al. In vitro activity of CEM-101 against Streptococcus pneumoniae and Streptococcus pyogenes with defined macrolide resistance mechanisms. Antimicrob. Agents Chemother. 54, 230-238 (2009).

166 Woosley, L. N., Castanheira, M. \& Jones, R. N. CEM-101 activity against Grampositive organisms. Antimicrob. Agents Chemother. 54, 2182-2187 (2010).

167 Putnam, S. D., Sader, H. S., Farrell, D. J., Biedenbach, D. J. \& Castanheira, M. Antimicrobial characterisation of solithromycin (CEM-101), a novel fluoroketolide: activity against staphylococci and enterococci. Int. J. Antimicrob. Agents 37, 39-45 (2011).

168 Putnam, S. D., Castanheira, M., Moet, G. J., Farrell, D. J. \& Jones, R. N. CEM-101, a novel fluoroketolide: antimicrobial activity against a diverse collection of Grampositive and Gram-negative bacteria. Diagn. Microbiol. Infect. Dis. 66, 393-401 (2010).

169 Takeda, S., Nakai, T., Wakai, Y., Ikeda, F. \& Hatano, K. In vitro and in vivo activities of a new cephalosporin, FR264205, against Pseudomonas aeruginosa. Antimicrob. Agents Chemother. 51, 826-830 (2007).

170 Toda, A. et al. Synthesis and SAR of novel parenteral anti-pseudomonal cephalosporins: discovery of FR264205. Bioorg. Med. Chem. Lett. 18, 4849-4852 (2008).

171 Ge, Y., Whitehouse, M. J., Friedland, I. \& Talbot, G. H. Pharmacokinetics and safety of CXA-101, a new antipseudomonal cephalosporin, in healthy adult male and female subjects receiving single- and multiple-dose intravenous infusions. Antimicrob. Agents Chemother. 54, 3427-3431 (2010).

172 US National Institutes of Health. ACT-179811 in Patients with Clostridium Difficile Infection (CDI) (NCTO1222702) <http://clinicaltrials.gov/ct2/show/NCT01222702〉 (accessed 4 April 2011).

$173 \mathrm{Jia}$, L. et al. Pharmacodynamics and pharmacokinetics of SQ109, a new diaminebased antitubercular drug. Br. J. Pharmacol. 144, 80-87 (2005).

174 Protopopova, M. et al. Identification of a new antitubercular drug candidate, SQ109, from a combinatorial library of 1,2-ethylenediamines. J. Antimicrob. Chemother. 56, 968-974 (2005).

175 US National Institute of Health. Early Bactericidal Activity (EBA) of SQ109 in Adult Subjects with Pulmonary TB (SQ109EBA) (NCT01218217) <http://clinicaltrials.gov/ ct2/show/NCT01218217> (accessed 4 April 2011).

176 Matsumoto, M. et al. OPC-67683, a nitro-dihydro-imidazooxazole derivative with promising action against tuberculosis in vitro and in mice. PLoS Med. 3, 2131-2144 (2006).

177 Sasaki, H. et al. Synthesis and antituberculosis activity of a novel series of optically active 6-nitro-2,3-dihydroimidazo[2,1-b]oxazoles. J. Med. Chem. 49, 7854-7860 (2006).

178 Singh, R. et al. PA-824 kills nonreplicating Mycobacterium tuberculosis by intracellular NO release. Science 322, 1392-1395 (2008).

179 Ginsberg, A. M., Laurenzi, M. W., Rouse, D. J., Whitney, K. D. \& Spigelman, M. K. Safety, tolerability, and pharmacokinetics of PA-824 in healthy subjects. Antimicrob. Agents Chemother. 53, 3720-3725 (2009).

180 Denny, W. A. \& Palmer, B. D. The nitroimidazooxazines (PA-824 and analogs): structure-activity relationship and mechanistic studies. Future Med. Chem. 2, 1295-1304 (2010).

181 Ahmad, Z. et al. PA-824 exhibits time-dependent activity in a murine model of tuberculosis. Antimicrob. Agents Chemother. 55, 239-245 (2011).

182 Goldstein, E. J. C. et al. In vitro activities of ABT-492, a new fluoroquinolone, against 155 aerobic and 171 anaerobic pathogens isolated from antral sinus puncture specimens from patients with sinusitis. Antimicrob. Agents Chemother. 47, 3008-3011 (2003).

183 Almer, L. S., Hoffrage, J. B., Keller, E. L., Flamm, R. K. \& Shortridge, V. D. In vitro and bactericidal activities of ABT-492, a novel fluoroquinolone, against Gram-positive and Gram-negative organisms. Antimicrob. Agents Chemother. 48, 2771-2777 (2004).

184 Lemaire, S., Tulkens, P. M. \& Van, B. F. Contrasting effects of acidic pH on the extracellular and intracellular activities of the anti-Gram-positive fluoroquinolones moxifloxacin and delafloxacin against Staphylococcus aureus. Antimicrob. Agents Chemother. 55, 649-658 (2011).

185 Emrich, N.- C., Heisig, A., Stubbings, W., Labischinski, H. \& Heisig, P. Antibacterial activity of finafloxacin under different $\mathrm{pH}$ conditions against isogenic strains of 
Escherichia coli expressing combinations of defined mechanisms of fluoroquinolone resistance. J. Antimicrob. Chemother. 65, 2530-2533 (2010).

186 Higgins, P. G., Stubbings, W., Wisplinghoff, H. \& Seifert, H. Activity of the investigational fluoroquinolone finafloxacin against ciprofloxacin-sensitive and -resistant Acinetobacter baumannii isolates. Antimicrob. Agents Chemother. 54, 1613-1615 (2010).

187 Morrow, B. J. et al. In vitro antibacterial activities of JNJ-Q2, a new broad-spectrum fluoroquinolone. Antimicrob. Agents Chemother. 54, 1955-1964 (2010).

188 US National Institutes of Health. Efficacy and Safety Study of JNJ-32729463 Compared with Moxifloxacin for the Treatment of Subjects Requiring Hospitalization for Community-Acquired Bacterial Pneumonia (NCTO1198626) < http://clinicaltrials. gov/ct2/show/NCT01198626> (accessed 4 April 2011).

189 Jones, R. N., Biedenbach, D. J., Ambrose, P. G. \& Wikler, M. A. Zabofloxacin (DW-224a) activity against Neisseria gonorrhoeae including quinolone-resistant strains. Diagn. Microbiol. Infect. Dis. 62, 110-112 (2008).

190 Park, H. S., Jung, S. J., Kwak, J.- H., Choi, D.- R. \& Choi, E.- C. DNA gyrase and topoisomerase IV are dual targets of zabofloxacin in Streptococcus pneumoniae. Int. J. Antimicrob. Agents 36, 97-98 (2010).

191 Arjona, A. Nemonoxacin: quinolone antibiotic. Drugs Future 34, 196-203 (2009).

192 Chung, D. T. et al. Multiple-dose safety, tolerability, and pharmacokinetics of oral nemonoxacin (TG-873870) in healthy volunteers. Antimicrob. Agents Chemother. 54, 411-417 (2009).

193 Lin, L. et al. Dose escalation study of the safety, tolerability, and pharmacokinetics of nemonoxacin (TG-873870), a novel potent broad-spectrum nonfluorinated quinolone, in healthy volunteers. Antimicrob. Agents Chemother. 54, 405-410 (2009).

194 Lauderdale, T.- L., Shiau, Y.- R., Lai, J.- F., Chen, H.- C. \& King, C.- H. R. Comparative in vitro activities of nemonoxacin (TG-873870), a novel nonfluorinated quinolone, and other quinolones against clinical isolates. Antimicrob. Agents Chemother. 54, 1338-1342 (2010)

195 Schneider, P., Hawser, S. \& Islam, K. Iclaprim, a novel diaminopyrimidine with potent activity on trimethoprim sensitive and resistant bacteria. Bioorg. Med. Chem. Lett. 13, 4217-4221 (2003).

196 Hawser, S., Lociuro, S. \& Islam, K. Dihydrofolate reductase inhibitors as antibacterial agents. Biochem. Pharmacol. 71, 941-948 (2006).

197 Krievins, D., Brandt, R., Hawser, S., Hadvary, P. \& Islam, K. Multicenter, randomized study of the efficacy and safety of intravenous iclaprim in complicated skin and skin structure infections. Antimicrob. Agents Chemother. 53, 2834-2840 (2009).

198 Sincak, C. A. \& Schmidt, J. M. Iclaprim, a novel diaminopyrimidine for the treatment of resistant Gram-positive infections. Ann. Pharmacother. 43, 1107-1114 (2009).

199 Skripkin, E. et al. $\mathrm{R} \chi-01$, a new family of oxazolidinones that overcome ribosomebased linezolid resistance. Antimicrob. Agents Chemother. 52, 3550-3557 (2008).
200 Zhou, J. et al. Design at the atomic level: design of biaryloxazolidinones as potent orally active antibiotics. Bioorg. Med. Chem. Lett. 18, 6175-6178 (2008).

201 Lemaire, S. et al. Cellular pharmacodynamics of the novel biaryloxazolidinone radezolid: studies with infected phagocytic and nonphagocytic cells, using Staphylococcus aureus, Staphylococcus epidermidis, Listeria monocytogenes, and Legionella pneumophila. Antimicrob. Agents Chemother. 54, 2549-2559 (2010).

202 Lemaire, S., Tulkens, P. M. \& Van, B. F. Cellular pharmacokinetics of the novel biaryloxazolidinone radezolid in phagocytic cells: studies with macrophages and polymorphonuclear neutrophils. Antimicrob. Agents Chemother. 54, 2540-2548 (2010).

203 Page, M. G. P., Dantier, C. \& Desarbre, E. In vitro properties of BAL30072, a novel siderophore sulfactam with activity against multiresistant Gram-negative bacilli. Antimicrob. Agents Chemother. 54, 2291-2302 (2010).

204 Mushtaq, S., Warner, M. \& Livermore, D. Activity of the siderophore monobactam BAL30072 against multiresistant non-fermenters. J. Antimicrob. Chemother. 65, 266-270 (2010).

205 Basilea Pharmaceutica. Basilea Initiates Phase I Clinical Program of its Novel Antibiotic BAL3007 (press release 23 November 2010) 〈http://www.basilea.com/ News-and-Media/Basilea-initiates-phase-I-clinical-program-of-its-novel-antibioticBAL30072/381> (2010).

206 Biedenbach, D. J., Jones, R. N., Ivezic-Schoenfeld, Z., Paukner, S. \& Novak, R. In vitro antibacterial spectrum of BC-7013, a novel pleuromutilin derivative for topical use in humans. 49th Interscience Conference on Antimicrobial Agents and Chemotherapy (San Francisco, CA), Poster F1-1521 (2009).

207 Craig, W. A., Andes, D., Ivezic-Schoenfeld, Z., Wicha, W. W. \& Novak, R. In vivo pharmacodynamic activity of BC-3205, a novel pleuromutilin derivative. 49th Interscience Conference on Antimicrobial Agents and Chemotherapy (San Francisco, CA), Poster F1-1504 (2009).

208 US National Institutes of Health. A Study in Healthy Volunteers to Assess Safety and Blood Levels of AZD9742 after Multiple Doses Over 14 Days (NCT01064388) 〈http://clinicaltrials.gov/ct2/show/NCT01064388〉 (accessed 4 April 2011).

209 Koul, A., Arnoult, E., Lounis, N., Guillemont, J. \& Andries, K. The challenge of new drug discovery for tuberculosis. Nature 469, 483-490 (2011).

210 Barbachyn, M. R. et al. Identification of a novel oxazolidinone (U-100480) with potent antimycobacterial activity. J. Med. Chem. 39, 680-685 (1996).

211 Wallis, R. S. et al. Pharmacokinetics and whole-blood bactericidal activity against Mycobacterium tuberculosis of single doses of PNU-100480 in healthy volunteers. J. Infect. Dis. 202, 745-751 (2010).

212 Williams, K. N. et al. Promising antituberculosis activity of the oxazolidinone PNU-100480 relative to that of linezolid in a murine model. Antimicrob. Agents Chemother. 53, 1314-1319 (2009). 